\title{
THE ROLE OF HYPOXIA AND PROTON MECHANISM OF PARIETAL CELLS IN THE OCCURENCE OF STRESS-INDUCED AND PEPTIC ULCERS
}

Based on experimental and clinical research, the authors revealed the preventive and therapeutic effect of continued intragastric delivery of molecular oxygen in case of stress-induced and peptic erosions and ulcers of stomach and duodenum. The hypothesis of possible role of hypoxia in the mechanism of injury of parietal cells is based on a consequence of transfer of protons from matrix of mitochondria and its further accumulation in cytoplasm. In this situation, the $\mathrm{H}^{+}$-dependent processes occur, particularly ATP synthesis and production of hydrochloric acid for which the protons are used.

KEY WORDS: stress-induced ulcers, peptic ulcers, hypoxia.

INTRODUCTION. Significant role of the occurrence of stress-induced, peptic ulcers and its resistance to the treatment is given to hypoxia [1-6].

The improvement of circulation of gastroduodenal zone, microcirculation of mucous layer of the stomach and duodenum, usage of antioxidants [2, 5], smoothing the metabolism are justified therapeutic methods in terms of ulcer pathogenesis. They are based on the principle of the recovery of adequate oxygen supply to cells according to their metabolic need. A good effect is observed because of the usage of oxygen (hyperbaric oxygenation [4, 6] with its enteric supply) in complex treatment of ulcer disease. It should be noted that oxygen therapy is delivered by seances (hyperbaric oxygenation $-50-60$ minutes every $2^{\text {nd }}$ day; enteric oxygen supply - by fractional method of 800 $1200 \mathrm{ml}$ every day). However the usage of oxygen therapy of short seances provides a short-lasting effect: after the cessation of gas supply, the partial pressure of oxygen in the tissues returns to previous values and adverse effect of hypoxia is retrieved. It stimulated us to develop a method of elimination of tissue hypoxia of gastrointestinal (GI) tract during the whole period of influence of negative factors and for the treatment of ulcer by using the continuous gastric oxygen therapy.

METHODS OF RESEARSH. In the experiment we discovered the peculiarities of stress-induced erosion and ulcer formation and in clinic - the treat-

(C) Ya. I. Honskyi, V. V. Hnativ, B. O. Pereviznyk, S. R. Pidruchna, I. P. Kuzmak, T. Ya. Yaroshenko, 2016. ment effectiveness for peptic ulcers: the elimination of hypoxia of mucous layer of $\mathrm{GI}$ tract by supplying the molecular oxygen with volume speed of 0.1$0.2 \mathrm{ml} \mathrm{min}^{-1} \cdot \mathrm{m}^{2}$ through the endonasal probe.

In animals (12 rats) we modeled stress-induced damage of mucous layer of the stomach by immobilizing them during 6 hours at the low temperature $\left(+4{ }^{\circ} \mathrm{C}\right)$. At such conditions we supplied the experimental group of animals (12 rats) with molecular oxygen by using the apparatus "Infuzomat" and the catheter.

This method of oxygen therapy was used in the treatment of ulcer disease of stomach and duodenum (in 22 patients - conservatively, in 46 - during the surgery and in post-operative period) [1]. The control group (20 patients) was formed of patients with the same pathology, who obtained the surgical treatment without using gastric oxygen therapy.

We evaluated the clinical data, motor-evacuation function of the stomach (electrogastrographically), endoscopic data, circulation of the organ (reographically - the apparatus RPG 2-02) and blood gases (the apparatus UNISTAT OXIMETER). The received data were statistically processed by using Student's $\mathrm{t}$-Test and compared to the data of control group of patients.

RESULTSANDDISCUSSION. In the experiment in control group of animals we detected the clinical pattern of expressed stress (low activity, low respiratory and heart rate, body temperature) and morphologically verified massive erosion and ulcers of mucous layer of the stomach. In experimented 
animals, which received oxygen into stomach cavity, we observed the following changes: rats were more active, the body temperature was on $(1.3 \pm 0.3){ }^{\circ} \mathrm{C}$ higher, the skin color, respiratory and heart rate were close to the normal values. Morphological research showed the cytoprotective influence of oxygen which was seen as the absence of stress ulcers in stomach mucous layer and no hypoxic damage of liver tissue in experimented animals compared to the control group.

At presence of lasting usage of continuous gastric oxygenation in complex therapy of conservative treatment of patients with peptic ulcer, the stomach mucous layer microcirculation repaired (verified reographically) and ulcer healing (verified endoscopically) occurred in 5-7 days earlier, than in patients of control group (20), which obtained standard treatment.

During the surgery of patients with penetrative ulcer we evaluated the effectiveness of oxygen absorption from stomach cavity. During continuous gastric oxygen therapy surgeons took blood from right gastroepiploic vein (in aseptic conditions). It was observed that the blood became of more bright red color compared to mixed venous blood. The significant increase in oxygen saturation of venous blood $(p<0.05)$ was seen. The data is provided in Table. Intragastric pressure didn't rise during the séance of oxygen therapy. It indicated on effective oxygen delivery from organ cavity into mucous layer cells, the following penetration of gas into a blood flow and elimination of tissue hypoxia.

During the postoperative period we observed early (from first hours) restoration of peristaltic moves of the bowels, decrease on $(60.5 \pm 15.0) \%$ of volume of stagnant stomach contents $(p<0.01)$ in 20 hours after the surgery. Spontaneous gas discharge was in $(32 \pm 3.4)$ hours earlier compared to patients of control group. It allowed prescribing enteric nutrition in 1.5 days earlier, decreasing the volume of infusion and transfusion therapy, and quickly activating the patient. The side effects during the gastric oxygen therapy were not observed in any patient.

How the mechanism of prophylactic and therapeutic effect of continuous gastric oxygenation can be explained?
According to the data of functional histology and physiology, the majority of erosions were localized in the fundus and body of the stomach (in the area of main glands). In the place of minor gastric curvature the most intensive (with higher acidity) gland secretion was observed as the response to the irritant. The most expressed structural changes of main and parietal cells were observed here as well, which ended up with ulcer formation (It was verified by us during the experiment).

Primary damages of stomach mucous layer in terms of stress came up on the level of parietal cells, which are responsible for hydrochloric acid production. Its production and discharge into $\mathrm{Gl}$ tract are the processes, which require great energy consumption.

The scientific papers review and the results of own research allowed us to suggest the generalized hypothesis for sequence of processes that lead to the formation of stress and peptic ulcers.

The primary factor of functional and morphological disturbance of stomach mucous layer cells is stress. The excessive discharge of stress hormones (adrenaline and glucocorticosteroids), induced by stress, leads to the increase of peripheral vascular tone and insufficient tissue microcirculation of visceral organs. At the same time adrenaline induces adenylate cyclase system: cyclic-AMP is produced, which stimulates the glycolysis as the only source of ATP synthesis in such conditions. Oxidative phosphorylation of ADP to ATP in terms of hypoxia is weak and cannot provide tissues with required energy in needed amounts.

Glycolysis leads to short-lasting energy supply. But its fast growth causes the acidification of internal environment of cells due to the lactate and pyruvate accumulation, which conversely inhibits glycolysis.

The acidification (the increase of $\mathrm{H}^{+}$concentration) is assisted by such factor that the hypoxia weakens tissue respiration and ATP-synthase of mitochondria, which in normal conditions products ATP due to proton potential or electrochemical gradient of $\mathrm{H}^{+}$ions. It is described in chemiosmotic theory of Peter Mitchell. According to this theory, there are 2 components that function on the level of mitochondrial membrane: osmotic - the diffe-

Table - The influence of gastric oxygen therapy on oxygenation of venous blood in patients with penetrative ulcers during the surgery $(\mathrm{M} \pm \mathrm{m})$

\begin{tabular}{|l|c|c|c|c|}
\hline \multirow{2}{*}{ Value } & \multicolumn{2}{|c|}{ Blood from right gastroepiploic vein } & \multicolumn{2}{c|}{ Mixed venous blood } \\
\cline { 2 - 5 } & $\begin{array}{c}\text { Gastric oxygen } \\
\text { therapy }\end{array}$ & $\begin{array}{c}\text { Patients of control } \\
\text { group }\end{array}$ & $\begin{array}{c}\text { Gastric oxygen } \\
\text { therapy }\end{array}$ & $\begin{array}{c}\text { Patients of control } \\
\text { group }\end{array}$ \\
\hline SB. $_{2,} \%$ & $82.4 \pm 1.8^{*}$ & $78.4 \pm 1.2$ & $75.6 \pm 1.4$ & $75.4 \pm 2.1$ \\
\hline Cв. $\left._{2,} \mathrm{ml} \cdot\right|^{-1}$ & $144.4 \pm 2.8^{\star *}$ & $136.6 \pm 2.5$ & $128.4 \pm 1.9$ & $128.1 \pm 2.0$ \\
\hline
\end{tabular}

Note. ${ }^{\star}-p<0.05 ;{ }^{* \star}-p<0.01$ compared to control group. 
rence of $\mathrm{H}^{+}$ions concentrations on both sides of inner membrane of mitochondria and electrical - the difference in electrical charge. The energy synthesis of ATP molecule from ADP and inorganic phosphate is followed with penetration of 2 protons from outside to the inside of mitochondrion. The created ATP is transported from matrix to intermembrane space and cell cytoplasm, where it is used due to the need.

Hypoxia and acidification of intracellular environment inhibit the ATP-synthase. The created ATP undergoes hydrolytic decomposition and $\mathrm{H}^{+}$ions are directed from matrix to the outer side of the inner membrane of mitochondria for supporting its membrane potential in order to save its vitality. Thereby, the flow of protons from matrix to intermembrane space and cell cytoplasm is the second explanation of acidification of cells by protons.

The carboanhydrase promotes the $\mathrm{H}^{+}$production in mucous layer, in particular, in parietal cells of the stomach by catalyzing the following chemical reaction:

$$
\mathrm{CO}_{2}+\mathrm{H}_{2} \mathrm{O} \rightarrow \mathrm{H}_{2} \mathrm{CO}_{3} \rightarrow \mathrm{H}^{+}+\mathrm{HCO}_{3}^{-}
$$

Normally, this reaction is the main one in generation of $\mathrm{H}^{+}$which are used for $\mathrm{HCl}$ secretion.

We can suppose that the primary damage of cells that product hydrochloric acid is caused by disturbance of these mechanisms. The parietal cells, besides of saving the structural integrity, are also obliged to implement their specific function of production and secretion of $\mathrm{HCl}$ into $\mathrm{GI}$ tract. $\mathrm{HCl}$ is composed of hydrogen cations - protons and chloride anions. Consequently, in these cells the competitive $\mathrm{H}^{+}$-dependent processes occur: the usage of protons not only for ATP synthesis, but for the production of $\mathrm{HCl}$ as well. The concentration of hydrogen ions in gastric juice is for hundreds and thousands times higher than in blood and other tissues.

Microorganisms such as Helicobacter pylori (H. pylori) currently get an important role in peptic ulcer formation. They stimulate the secretion of hydrochloric acid and obviously inhibit the activity of $\mathrm{H}^{+}$-ATP-synthase by decreasing the processes of energy formation of cells.

The acidification of intracellular environment of mucous layer and the limit of ATP synthesis promotes such following defects in normal cell functioning as: at $\mathrm{pH}=5.0$ the lysosomal hydrolases are activated; deficiency of ATP depresses the function of transportATP-dependent systems $\left(\mathrm{Na}^{+}, \mathrm{K}^{+}\right.$ATPases, $\mathrm{K}^{+}, \mathrm{H}^{+}$-ATPases, anion-sensitive ATPases). Consequently, $\mathrm{Na}^{+} \mathrm{i} \mathrm{Ca}^{2+}$ ions, which came into cells due to the concentration gradients, will be accumulated and will also delay electroneutral $\mathrm{Cl}^{-}$. The outcome of it is an "osmotic shock" inside the cell: hydrophilic ions, by increasing the osmotic pressure, hold the water and cause cell cytolysis (the damage of plasmatic membranes).

On the level of mucous layer it macroscopically appears as the acute erosion. The significant role in pathogenesis of peptic ulcer is given to the imbalance between local protective factors of the mucous layer and the aggression factors. The appearance of peptic ulcer of duodenum is assisted by metaplasia of gastric epithelium to it, where the colonization of $\mathrm{H}$. pylori occurs and consequently causes ulcer.

These considerations are presented in scheme 1.

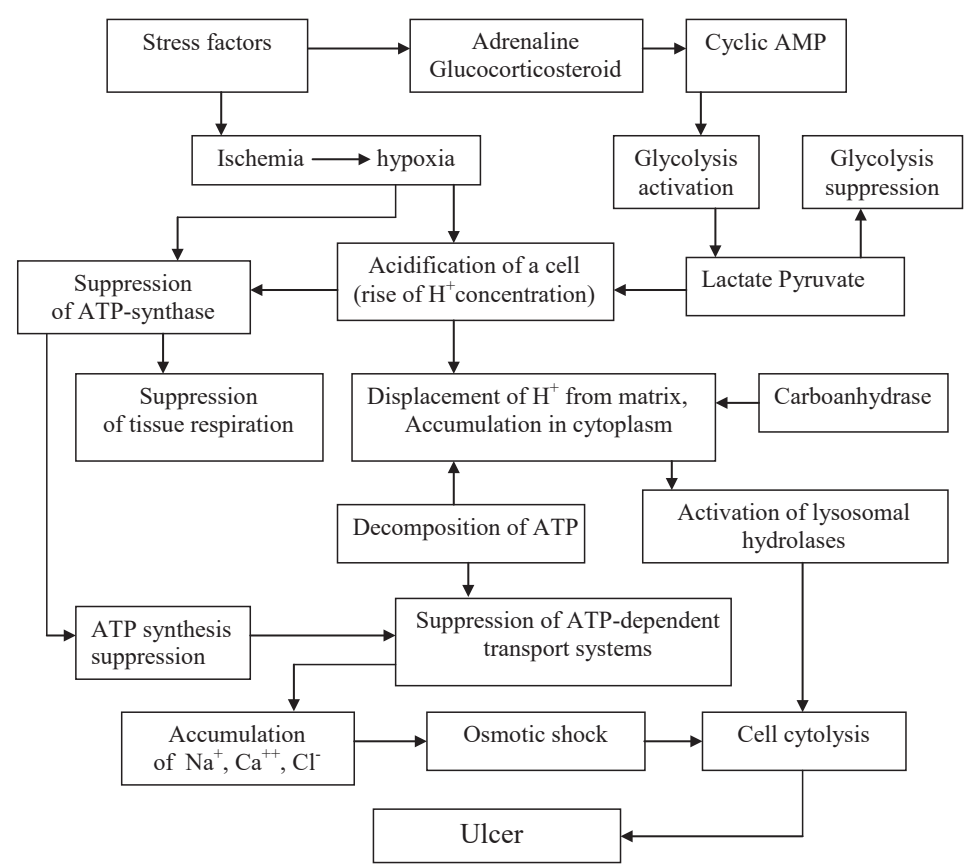

Scheme 1. The role of hypoxia and proton mechanism in ulcer formation. 
The truthfulness of this hypothesis is proved by the formation of opposite conditions for the cell: the oxygen that is supplied to the stomach is effectively absorbed through mucous layer and saturates tissues by passing the vessels due to the pressure gradient. As being the terminal acceptor of electrons, it promotes the normalization of oxidative phosphorylation, flattens all the energy-dependent reactions in cells and their structural reparation (scheme 2). Besides, the high concentration of oxygen in gastro-intestinal tract implements a bad influence on $\mathrm{H}$. pylori, as it belongs to facultative aerobe and optimally develops in the environment of oxygen concentration of $5 \%$.

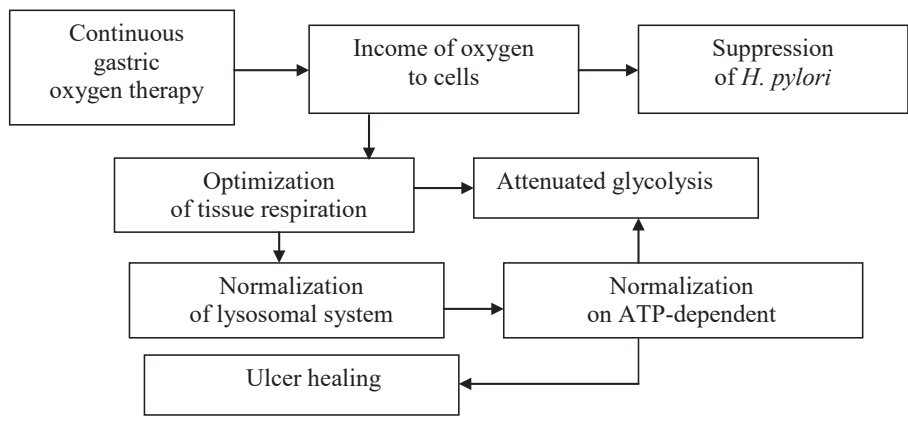

Scheme 2. The influence of continuous gastric oxygen therapy on ulcer healing.

CONCLUSIONS. The suggested hypothesis of the role of hypoxia and defect of proton gradient in formation of stress and peptic ulcers to some extent explains the protective and treatment effect of continuous gastric oxygen therapy. Additionally, this method in clinical conditions indicates on the necessity of further studies concerned to the influence of molecular oxygen on the functional state of GI tract (secretory function of stomach and intestines) and its effect on eradication of $\mathrm{H}$. pylori.

\section{REFERENCES}

1. Безперервна тривала гастроінтестинальна оксигенотерапія в абдомінальній хірургії / [Л. Я. Ковальчук, В. В. Гнатів, А. Д. Беденюк та ін.] // Матеріали наук.практ. конф. хірургів Тернопілля. - Тернопіль : Укрмедкнига, 2002. - С. 99-100.

2. Das D. Effect of stress on the antioxidant enzymes and gastric ulceration / D. Das, R. K. Banerjee // Molecular \& Cellular Biochemistry. - 1993. - 125, № 2. - P. 115-125.

3. Effects of mono- and combined peptic ulcer therapy on lipid peroxydation and antioxidant defense in ulcerous zone / E. M. Esedov, S. N. Mamaev // Klinicheskaia Meditsina. - 1998. - 76, № 1. - P. 28-31.

4. Hansen J. Intensive Therapy under the conditions of $\mathrm{HBO} / \mathrm{J}$. Hansen, J. Weiher. $-10^{\text {th }}$ Eurropean Congress of Anaestesiology, 1998. - P. 382.

5 . Anemia in relation to body mass index and waist circumference among Chinese women / Y. Qin, A. MelseBoonstra, X. Pan [et al.] // Nutr. J. - 2013. - 12. - P. 10.

6. Lee B. J. Identification of Hemoglobin Levels Based on Anthropometric Indices in Elderly Koreans / B. J. Lee, J. Y. Kim // PLoS ONE. - 2016. - 11. № 11.

Я. І. Гонський, В. В. Гнатів, Б. О. Перевізник, С. Р. Підручна, І. П. Кузьмак, Т. Я. Ярошенко ТЕРНОПІЛЬСЬКИЙ ДЕРЖАВНИЙ МЕДИЧНИЙ УНІВЕРСИТЕТ ІМЕНІ І. Я. ГОРБАЧЕВСЬКОГО

\section{РОЛЬ ГІПОКСІЇ ТА ПРОТОННОГО МЕХАНІЗМУ ПАРІЄТАЛЬНИХ КЛІТИН У ВИНИКНЕННІ СТРЕСІНДУКОВАНИХ І ПЕПТИЧНИХ ВИРАЗОК}

\section{Резюме}

На основі експериментальних та клінічних досліджень автори виявили попереджувальний і лікувальний ефект від безперервного тривалого внутрішньошлункового введення молекулярного кисню при стресо- 
вих та пептичних ерозіях і виразках шлунка та дванадцятипалої кишки. Запропоновано гіпотезу щодо ролі гіпоксії в ушкодженні парієтальних клітин внаслідок переміщення протонів з матриксу мітохондрій та накопичення їх у цитоплазмі. При цьому в клітинах відбуваються конкуруючі, $\mathrm{H}^{+}$-залежні процеси (синтез АТФ та продукування хлористоводневої кислоти), на забезпечення яких використовуються протони.

КЛЮчОВІ СЛОВА: стресіндуковані виразки, пептичні виразки, гіпоксія.

Я. И. Гонский, В. В. Гнатив, Б. О. Перевизнык, С. Р. Пидручная, И. П. Кузьмак, Т. Я. Ярошенко ТЕРНОПОЛЬСКИЙ ГОСУДАРСТВЕННЫЙ МЕДИЦИНСКИЙ УНИВЕРСИТЕТ ИМЕНИ И. Я. ГОРБАЧЕВСКОГО

\section{РОЛЬ ГИПОКСИИ И ПРОТОННОГО МЕХАНИЗМА ПАРИЕТАЛЬНЫХ КЛЕТОК В ВОЗНИКНОВЕНИИ СТРЕССИНДУЦИРОВАННЫХ И ПЕПТИЧЕСКИХ ЯЗВ}

\section{Резюме}

На основе экспериментальных и клинических исследований авторы обнаружили предупредительный и лечебный эфрфект от непрерывного длительного внутрижелудочного введения молекулярного кислорода при стрессовых и пептических эрозиях и язвах желудка и двенадцатиперстной кишки. Предложена гипотеза относительно роли гипоксии в повреждении париетальных клеток вследствие перемещения протонов из матрикса митохондрий и накопления их в цитоплазме. При этом в клетках происходят конкурирующие, $\mathrm{H}^{+}$-зависимые процессы (синтез АТФ и продуцирование соляной кислоты), на обеспечение которых используются протоны.

КЛЮЧЕВЫЕ СЛОВА: стрессиндуцированные язВы, пептические язВы, гипоксия.

Received 02.11.16

Address for correspondence: S. R. Pidruchna, I. Horbachevsky Ternopil State Medical University, Maidan Voli, 1, Ternopil, 46001, Ukraine e-mail: pidruchna@tdmu.edu.ua. 